\title{
The Vicious Cycle of The Effects of School Building Construction Abandonment: Beneficiary's Perspective
}

\author{
Isaac Sakyi Damoah ${ }^{1 *}$ and Anthony Ayakwah ${ }^{2}$ \\ ${ }^{1}$ Executive Business Centre, UK \\ ${ }^{2}$ Department of Business and Management Studies, Koforidua Technical University, Ghana
}

Submission: October 26, 2019; Published: November 12, 2019

*Corresponding author: Isaac Sakyi Damoah, Executive Business Centre, EBC 50189 Holdenhurst Road Bournemouth BH8 8EB, UK

Abstract

Purpose: Public sector school building construction plays an important role in national education. However, in developing countries, some of these projects are not completed but researchers have not paid attention to the vicious cycle effects on the beneficiaries of such projects. To this end, this study explores the effects of public sector school building abandonment by using Ghanaian Community Day Senior High School building as a case study.

Methodology: Qualitative research design which constituted 20 in-depth semi-structured interviews to solicit the views of definitive stakeholders (project management practitioners, contractors, and clients) who have been involved in an uncompleted (abandoned) public sector Community Day Senior High School building construction projects. Results were analyzed using thematic and content analysis techniques.

Findings: The findings indicate that the impact of the Community Day School building construction project abandonment has three main effects on the beneficiaries. These effects are social, economic and politically related. However, the three effects are intertwined and cyclical. Thus, there are several immediate social effects on the beneficiaries, but these social effects have long-term economic and political implications for the citizens in the form of citizen's economic development and their attitude towards governments and their voting behavior in general elections.

Research Limitations: The main caveat of this study is that we used quota in the data selection and as such, it may not represent the views of the entire population. However, since we do not intend to generalize as this is an exploratory study, further studies could increase the sample size to improve generalizability. Given that individuals were contacted on the basis that they have been involved in abandoned the public sector building Community Day School building construction projects, we have no reason to doubt their views.

Practical Implications: Policymakers and practitioners will be able to understand the effects of school building construction projects abandonment. This will help them to devise strategies that will help reduce or avoid such abandonment and its subsequent effects on the stakeholders-beneficiaries. Further, researchers would be able to use findings as a foundation for further research into public sector projects abandonment phenomenon in general and school buildings.

Originality: Unlike prior studies that have often assessed effects of construction projects abandonment on the projects being assessed, this study assessed effects of abandonment on the beneficiaries-an area that has been neglected by researchers.

Keywords: Community day school; School building; Project abandonment; Public sector construction

\section{Introduction}

This research investigates the effects of school building construction project abandonment on the beneficiaries by focusing on the Ghanaian public sector. Government policies are often translated into programs and projects [1]. One such area in which programs and projects are implemented is within the public education sector-which includes school building construction. These projects require a huge capital outlay and successful completion is essential for education progress and development. However, existing evidence suggests that some of these projects never get completed (abandonment). Abandonment, which is often described as a project that has been totally or partially abandoned [2] has become a rule rather than exception in public sector construction execution in developing countries like Ghana [3-5]. However, studies looking at effects of projects abandonment have concentrated on the effects on the completion of the projects being assessed [6-8] to the neglect 


\section{Civil Engineering Research Journal}

of the stakeholders associated with such projects. This study bridges this research gap by looking at the effect concerning the stakeholders by focusing on the beneficiaries using the Ghanaian Community Day Senior Secondary School Building as a case study.

School building construction projects have become essential components of successive governments' policies in Ghana due to the deficit in school building infrastructure [9-10]. Successive governments have made conscious efforts to reduce the deficit through various programmes and projects. One mega-project within the school building project sector in recent years is the construction of 200-Community Day Senior High Schools [9]. However, available evidence suggests that only 50 have been completed whiles the remaining 150 have been abandoned at various stages of completion as a new government was sworn into office in 2016 [11-14]. Further, some of the very few completed ones are not in used and have been left in the bushes to the mercy of the weather; hence, the need to investigate the effects of abandonment on the beneficiaries. We focused on the effects of Ghana's public sector school building abandonment on beneficiaries because Ghana typifies a developing country with many happenings in the education sector in many developing countries. Further, Ghana represents many developing countries where construction project abandonments have become a rule rather than an exception. As a result, findings will have implications for policymakers and practitioners undertaking public sector school building projects. The reminder of the study is presented as follows: section two reviews theoretical foundation of the study by explaining how stakeholder theory supports the research. Section three reviews related literature on effects of projects failure in general and effects of construction projects abandonment in particular. Section four presents the methodology and data collection approaches whilst section five presents the results and discussions of the findings. The last section concludes the study by summarizing the key findings and teases out the main contribution of the study to both practitioners and academics.

\section{Theoretical Framework}

\section{Stakeholder theory}

The theoretical foundation of this study is based on stakeholder theory-thus, we use stakeholder theory to explain how school building projects abandonment affects the beneficiaries in a vicious cycle. Stakeholder theory was first propounded by Freeman [15] and it states that a stakeholder is any organization or individual who can affect or be affected by the operations and achievements of an organization's objectives. The foundation of the theory is based on the claim that organizations have "ethical duty to stakeholders above and beyond what is required by law and, in particular, ethical duties that require the firm to operate in ways that will foreseeably reduce long-term profits" [16]. In agreement with prior studies, stakeholders in project management are those individuals or institutions who can affect or be affected by the management and deliverables of the project [17-19].

Even though the theory was first used in strategic management [15], it has since been applied in many subject areas. Among them is project management-the past two decades has witnessed significant application of the stakeholder theory in project management research and practices. Pan [17], Pan \& Pan [18], Saebo \& Axelsson et al. [20,21] have used the theory in the identification and management of stakeholders in project management. The early development and application of the stakeholders' theory were mainly in the private sector. However, the awareness of the numerous stakeholders associated with public sector management, has witnessed a steady rise in the application of the theory in the public sector; and public sector project management is no exception $[17,18,20,22,23]$. In the case of Elias et al. [22] for instance, they used the stakeholder theory to highlight research and development (R \& D) project management in New Zealand. In a similar study, Olander [19] used the stakeholder theory to analyse the impact of stakeholders on construction project management. Drawing on the above studies, we adopt the stakeholder theory to explain how public sector school building construction projects abandonment affects the beneficiaries.

\section{Stakeholders associated with Ghanaian community day school building project}

Stakeholder identification approach and techniques have been a cause of disagreement in the literature. Whilst the majority have offered a practical approach to the identification processes, others have offered a theoretical perspective to it. Regarding the former, Alexander \& Stevens [24] offered practical guidance to the stakeholder identification processes using a firm's managerby listing down all the necessary parties involved in project management activities. Similarly, Alexander \& Robertson [25] offers stakeholder identification processes using the onion model' to locate the various stakeholder groups within each "ring" of the onion. However, this approach does not consider the context-specific frame of the project being executed.

Regarding the latter, Mitchell Agle \& Wood [26] offers a theory call stakeholder salience-which has been applied extensively in project management researchers [17-19,22]. The stakeholder salience states that a stakeholder has three main attributespower (ability to influence the firm), legitimacy (relationship between stakeholder and the firm on the basis of contracts and legal title), and urgency (the degree to which managerial delay in attending to the claim is unacceptable to stakeholders). The stakeholder salience further asserts that, in order to qualify to be classified as stakeholder, the individual(s) must possess at least one of the salience (power, legitimacy and urgency). On the basis of the three attributes, Mitchell et al. classified stakeholders further into seven (7)- Dormant, Discretionary, and Demanding, Dominant, Dangerous, Dependent and Definitive stakeholders' groups. One, Dormant stakeholders-possess the power to 
impose their will but do not have any legitimate relationship or urgent claim, and that their power remains unused. Two, Discretionary stakeholders-possess legitimacy but have no power or urgent claims, hence, there is no absolute pressure on firm's management to engage them in an active relationship. Three, Demanding stakeholders-these stakeholder have urgent claim but have no power or legitimate relationship. They may be of a bother to management, but this may not necessarily warrant engagement. Four, Dominant stakeholders-they have power and legitimacy, but no urgent claims and as such their action may affect the management. Five, Dangerous stakeholders-they have power and urgency but has no legitimacy. Theses stakeholders may be coercive and violent, therefore, are 'dangerous' to the operations of the organization. Six, Dependent stakeholders-have legitimacy and urgency but do not have power, and as such rely on others through coalition for power to carry on their wishes. Lastly, Definitive stakeholders-have power and legitimacy and as such their claims need to be given priority. They are often the dominant stakeholders of the focal organization. Based on the stakeholder salience categorization, the Table 1 below provides the categorization of the Ghanaian public sector community day school building construction projects stakeholders. However, for this study, we focus the effects on the beneficiaries who are mainly the students and their parents-the general citizens. Adopted from Damoah et al. [27].

Table 1: Stakeholder Identification Matrix for Ghanaian Public Sector School Building Construction Project.

\begin{tabular}{|c|c|c|c|c|c|}
\hline Stakeholder Classification & Stake Holders & \multicolumn{3}{|c|}{ Attributes of Salience } & \multirow{2}{*}{$\begin{array}{c}\text { Sub-Classification } \\
\text { (Type) }\end{array}$} \\
\hline \multirow{4}{*}{$\begin{array}{c}\text { Latent stakeholder ( } 1 \text { attributes) Low } \\
\text { salience }\end{array}$} & & Power & Legitimacy & Urgency & \\
\hline & & $\mathrm{X}$ & & & Dormant \\
\hline & & & $\mathrm{X}$ & & Discretionary \\
\hline & Media & & & $\mathrm{X}$ & Demanding \\
\hline \multirow{6}{*}{$\begin{array}{l}\text { Expectant stakeholders ( } 2 \text { attributes) } \\
\text { Moderate salience }\end{array}$} & Donor agencies and countries & $\mathrm{X}$ & $\mathrm{X}$ & & Dominant \\
\hline & Financial institutions & $\mathrm{X}$ & $\mathrm{X}$ & & Dominant \\
\hline & Local communities & $\mathrm{X}$ & & $\mathrm{X}$ & Dangerous \\
\hline & Contractors & & $\mathrm{X}$ & $\mathrm{X}$ & Dependent \\
\hline & Local businesses & & $\mathrm{X}$ & $\mathrm{X}$ & Dependent \\
\hline & General public/citizens & & $\mathrm{X}$ & $\mathrm{X}$ & Dependent \\
\hline \multirow{3}{*}{$\begin{array}{c}\text { Definitive stakeholders ( } 3 \text { attributes) } \\
\text { Definitive salience }\end{array}$} & Government (Client) & $\mathrm{X}$ & $\mathrm{X}$ & $\mathrm{X}$ & Definitive \\
\hline & $\begin{array}{l}\text { Project management } \\
\text { Practitioners }\end{array}$ & $X$ & $\mathrm{X}$ & $X$ & $X$ \\
\hline & Consultants (auditors) & $\mathrm{X}$ & $\mathrm{X}$ & $\mathrm{X}$ & $\mathrm{X}$ \\
\hline
\end{tabular}

\section{Literature Review}

\section{Effects of construction projects failure}

Extant literature suggests that several factors account for project failure. Even though failures in the context of prior studies were not specifically defined within the remit of abandonment, it could be extended to abandonment. For example, Sambasivan and Soon identified time overrun, cost overrun, disputes, arbitration, litigation and total abandonment as the effects of projects failure. Pourrostam \& Ismail [7] identified time overrun, cost overrun, disputes, arbitration, total abandonment, and litigation as the main effects of projects failure [7]. Similarly, researched the effects of construction project delays in Nigeria and found that all the effects relate to the project's completion.

Research into material and equipment procurement delays in highway projects in Nepal also found that this has negative effects on the projects' completion [28]. Identified extension of time, cost overruns, loss of profits, disputes, poor quality of work, stress to the clients, acceleration losses, bad reputation with contraction team, claims, delays in getting profits by the client, creates stress on the contractors, delaying the client to repay back the bank loans, bad reputation with client, termination of contracts, arbitration, bankruptcy of the client, idling resources, litigation, total abandonment and loss of skilled employees as the main effects of construction projects delays in South Africa. Similarly, Amoatey et al. [8] identified the effects of delays in construction projects failure in Ghana as cost overrun, time overrun, litigation, lack of continuity by client and arbitration. It can be deduced that the effects of the project failure are mainly on the projects being executed, hence, the effects on beneficiaries' needs researchers' attention.

\section{Effects of construction projects abandonment on stakeholders}

Regarding abandonment, Ayodele \& Alabi [3] identified wasted resources and loss of tax revenue by the government and other stakeholders associated with development projects as the main effects of abandonment. Ngacho \& Das [29] also observed that abandonment of projects have socioeconomic effects on the citizens; however, they failed to mention the 
specific socio-economic effects. Similarly, Efenudu [6] found that the main effect of abandonment is lowering of the value of the properties. Investigated the effects of development projects abandonment in real property values in Nigeria and found eight (8) main effects; which includes: it affects the real property total values reduction; it affects the total income receivable from real property; it becomes a disappointment to the owner and the populace; it increases the negative effects of environmental issues on the real property and the built environment; it negatively reduces the motivation to attract investment in real properties; it becomes a waste of financial and material resources; employment opportunities in real property and other sectors are impacted negatively; and it deprives the government of the expected revenue from property tax.

In Malaysian housing projects' abandonment, the abandonment effects is that house buyers will still pay for houses before they handed over at a later date. In Urbanization projects in Spanish coast, the main effects of abandonment is environmental and socio-economic effects which relates to: visual effects, landscape modification, biodiversity decrease and increased pollution; and unemployment, conflicts between public administration and private sector, loss of economic value of the area, marginalization of the population and transfer of cost between the private and public sector.

Even though significant research has been conducted into project abandonment in general and construction project abandonment in particular, no study has exclusively looked at the effects of abandonment on the beneficiaries with particular emphasis on school building infrastructure project. Therefore, this augurs well for an investigation into such an area-which will add to the growing literature on effects of projects failure on stakeholders.

\section{Methodology}

Table 2: Respondent Categories.

\begin{tabular}{|c|c|c|}
\hline Respondent Categories & Number & Type of Engagement \\
\hline $\begin{array}{c}\text { Project Management } \\
\text { Practitioners (PMP) }\end{array}$ & 5 & $\begin{array}{c}\text { Semi-structured } \\
\text { Interview }\end{array}$ \\
\hline Contractors (C) & 5 & $\begin{array}{c}\text { Semi-structured } \\
\text { Interview }\end{array}$ \\
\hline General Public (GP) & 5 & $\begin{array}{c}\text { Semi-structured } \\
\text { Interview }\end{array}$ \\
\hline Government Officials (GO) & 5 & $\begin{array}{c}\text { Semi-structured } \\
\text { Interview }\end{array}$ \\
\hline Total & 20 & \\
\hline
\end{tabular}

The data for this study were collected from twenty (20) definitive stakeholders association with Ghanaian public sector school building construction using purposive sampling selection techniques. They came from four sets of stakeholders as shown in Table 2 below. Project management practitioners, contractors and public officials were directly contacted by organizations and institutions involved in the project whilst the public was selected from local communities where the abandoned community day school building projects were sited. We used quota-sampling technique to determine the sample size.

Prior to the data collection, four pilot interviews were conducted-this was to ensure that questions are valid and understood by the local context [30]. The full interview was conducted in English and Twi-the official language and the most popular language in the country; which lasted up to one hour each. This was conducted between July 2017 and September 2017. Interviews were conducted in places of convenient for respondents. As a result, initial contacts were made to individuals using professional survey enumerators. Prior to the interviews, a pre-booking of an appointment with the respondents was made; which provided a conducive atmosphere which allowed the respondents to feel comfortable. The data were analyzed using thematic data analysis techniques. Each data was uploaded to NVivo software after the description. We reduced the data by selecting, focusing and condensing the information collected. A line-by-line approach was used to identify the codes that relate to specific themes. This was followed by coding the content and cross-cases. Sentences were coded to explain the main themes identified. Axial coding was then carried out to identify the patterns and relationships between the various effects of the public sector school building construction projects abandonment on beneficiaries [31]. The results are then presented as prescribed by Braun \& Clarke [32].

\section{Results and Discussion}

\section{The effects of school building construction projects abandonment}

The results revealed three key effects of school building construction projects failure on the beneficiaries. These are social, economic and political related effects. However, these are intertwined and cyclical in nature. The respondents said that if public school buildings are abandoned, the immediate effects is that either school attendance is run on the shift system or students are dropped out. For instance, GO1 said that: "I think the immediate effect of abandonment of the community day SHS school building abandonment is the shift system which is being carried out by the current government. There are not enough buildings to accommodate all the students, especially now that there is free SHS with more intakes. People say, it's because of the free SHS, thus why there is a sift system but that is not the only reason ... the community day schools could have accommodated all of them at once had it not been abandoned. The current government has promised to continue but I am sure if they will since it's not their project"

However, they were of the view that both the shift system and students drop-out have immediate social effects and longterm economic and political effects. G01 added that: "The social effects of this sift system or school drop-out is huge and in cycle-some will call it vicious cycle ...one of the effect will lead to 
another effect. I want to emphasize that the social effect on the children and their parents is in cycles, the gangs and children gambling and doing all sorts of social vices are all from these school drop-out family. Elsewhere, where I did my masters [degree], you can be a school drop-out and still can make end meet but not in this country ...in this country, education is very important for the long-term sustainability of the family. If your family is poor, the only ways to get out of it is education, so if you drop-out because of school building abandonment, then you have no hope for you and your future generations."

Those arguing for the immediate social effects argue that the shift system allows a significant gap in terms of time spent in school and that some students end up indulging in social vices such as deft, gambling, hang-out with friends, gangs, among others. For example, GP1 opined that: "I think the key success factor is effective and excellent communication among the key stakeholders. In this country, sometimes it's difficult to speak to those in higher authorities ... you have to go through a lot of bureaucratic and protocol to speak to those in authorities. So, if there is specific communication plan, and everybody [stakeholders] knows whom to speak to and they know that they have the duty and accountability to the victims or the ordinary citizens, then, disaster operations will be easy and successful [R1] have you not heard of the on-going political debate about the shift system and the possibility of ."

They attributed this mainly to poorer families. PMP4 and GP5 said that, most often parents from poorer families are not able to monitor their wards as to whether they are in shift A or B due to illiteracy and students from such families take advantage of that to stay away from school to engage in social vices. GP5 for example said:

"These effects that we are talking about normally happen to poorer and illiterates' families ... and that most educated and well to do families have enough knowledge and time to monitor their wards through the sift system. And in drop-out, I can say it's only the poor and those in the villages that suffer the most of not only them ...this is because educated and rich people will do anything possible to send their kids to another school if they do not get into such [community day] school. I think you should restrict your research to the poor and village dwellers since they are those who suffer the most"

Thus, others (PMP2-4, GP1) added that in some situations, students are able to trick their parents that they are in a particular shift but in actual sense they belong to another shift. They deliberately do that to sway their parents in order to stay at home. This has consequences on their educational growth and national development since lack of education affects the skill-sets of the citizens, hence, affecting their contributions to the national economic development. On the other hand, school drop-out can occur if the shift system is not in place. They opined that in most cases it leads to teenage pregnancy (P4, P5 \& GO3).
According to them, teenage pregnancy becomes a "vicious cycle" since they (teenagers) often end up giving birth to children without responsible fathers. "The school drop-out effect is a vicious cycle, trust me, those who drop-out are the same people who end up on the streets and mostly become irresponsible parents, some do get pregnant without knowing their children's father." The implications according to the respondents (GP3-5, G02-5) are that, children from such irresponsible parents will end up being school drop-out if the necessary measures are not put in place. "...the problem is that it's the same people who fail to attend school or drop-out whose children end up on our streets. In advanced countries such as UK and US, parents could be prosecuted for allowing their children to be on the streets but here [Ghana], you cannot do that. There are laws that can allow us to do it but enforcing it extremely is difficult due to the economic situation over here." (G04).

Similarly, found socio-economic effects of construction project abandonment; however, their findings related to urbanisation projects that have environmental and socioeconomic related impact. Politically, respondents perceive that if school buildings are abandoned, students and parents living in such communities speaks against the government who abandoned the project. Consequently, it affects the political party they choose to vote for in an election. One government official said,

"We are aware of the political implications of projects abandonment; I am not referring to the community day school building here because it cut across all governments projects -especially infrastructural projects. They people [citizens]-especially those living in the villages only care about infrastructural projects performance, most of them have no idea about monetary and fiscal policy indicators, so that is the only way the use to judge the government's performance, so abandonment of such projects can affect how they vote for you or against you." This finding is echoed in the work of Amponsah [33], Damoah \& Akwei [34]. However, their study looked at the influence on government projects performance and failure respectively whilst this current research assesses politics from effects of abandonment perspective. The implication is that since every public sector school building construction project abandonment is associated with the government's political fate, the government would need to ensure that such projects are completed on time.

They further revealed that not only the local community where the abandoned projects are sited vote against the implementing government, but it also has ripple effects on the country as a whole. Referring the case study (community day SHS), the respondents said, it was one of the main campaign tools for the opposition party in the 2016 general election; and it was a national campaign message. In the words of one of the project management practitioners: "I can tell you that the community day school building was one of the main campaign 


\section{Civil Engineering Research Journal}

tools for both the incumbent and the opposition [political] parties during the 2016 general elections. Whilst the government added to its green book [the book containing the governments infrastructural achievements], the opposition argued that the more than 3/4th of the projects had not been completed. This had significant impact on the votes [during the general election in 2016] (PMP5)."

One government official echoed this and said: "In Ghana, every government activity has political implications ... most of the people do not understand governance, so they attribute every good or bad happenings in the country to the government, even if it's the fault of the contractor or civil servant. Sometimes, I do not blame them ...this is because they [politicians] would want to claim every glory in the public sector for political gain. (G02)." Even though extensive study into project management failure in general [35] and construction in particular $[3,8]$ have cited politics as a factor that causes failure; they did not espouse this problem as an effect. Hence, this study adds different dimensions to the relationships between political and public sector project implementation. However, Goodman \& Love's [1] assertions that government policies are often translated into programs and projects support this assertion. This suggests that public sector school building project failure through abandonment could determine the political fate of the implementing government. Thus, the implication is that politics in developing countries do not only affect public sector projects performance but also the abandonment of such projects could have political repercussions. Regarding the economic effects of abandonment on the beneficiaries, the study revealed several of economic effects. Respondents said that when such school buildings are abandoned, it has long-term economic effects on the beneficiaries and the country. Concerning the beneficiaries, their financial abilities do not improve. One contractor said: “Financially, beneficiaries' financial situation will not improve since education enhances people's ability to access gainful employment that will improve their financial standing. (C4)" On the other hand, it affects the economic development of the country since such people (those affected by abandonment) do not contribute meaningfully to the economy. One project management practitioner said:

"How can families affected by such problems of abandonment contribute meaningfully to the Ghanaian economy? They often become a burden to the society, especially their immediate family. Some of them end up prison and the government and the family spend a lot of money on them at the prisons instead of using the money to do something meaningful that will contribute to the economy" (PMP2).

The study further revealed that it brings about cost escalation due to price fluctuation and inflation, but they said this will eventually be borne by the taxpayers. C5 quizzed: "if there is cost escalation on these project, who pays? Is it not the same taxpayers? They [citizens] have no idea that it's their own monies that are used to fund these projects. So, to me, every effect of the abandonment of government projects failure is on the citizens, especially the poor ones."

However, they perceived that this would have long-term repercussions on the citizens-thus, if the economic development of the country is retarded, the public suffers. In the words of GP4: "... who suffers the most when there general economy of the country is suffers ...it is the same poor uneducated people mostly living in our villages who suffer the consequences. It's a big problem here in Ghana. I understand you are only looking at the community day schools' abandonment. However, this is not the only school building project that has been abandoned. Abandonment is everywhere and the problem [effects] is the same everywhere ...this one [community day school] is popular because of the politics they [politicians] played with the situation in the run up to 2016 [general] elections." GP5 added, "do not look far from the ordinary poor Ghanaians when it comes to who suffers the most when there is economic difficulty in the country".

This finding is supported by prior studies that have concluded that the public sector development becomes retarded as the public sector project is a panacea to a country's development [35-38]. Further, this finding is similar to the work of $[29,39,40]$ which observed that international development projects have socio-economic effects on the citizens since such projects seeks to improve on their socio-economic development through addition of soft and hard skills to the citizens; nevertheless their study only made mention of these types of effects without discussing into detail how stakeholders may be affected through a vicious cycle. Similarly, Pinto [41] observed that project-based activities have become a critical component of global industrialization. By extension and interpretation, failure of such projects through abandonments will impact negatively on a country's citizens and their national development. By extension, abandonment of school buildings leading to economic underdevelopment of citizens within Ghana and similar countries will affect the overall national development. The implication is that public sector school building projects' successful completion is critical to the nation's long-term development of the citizens and that of the country [42-44].

\section{Conclusion, Limitations and Future Research}

\section{Conclusion}

Public sector school building construction plays an important role in national education. However, in developing countries, some of these projects do not get completed, but researchers have not paid attention to the vicious cycle effects on the beneficiaries of such projects. To this end, this study explored the effects of public sector school building abandonment by using Ghanaian Community Day Senior High School buildings as a case study. We used an in-depth semi-structured interview to solicit the views of definitive stakeholders (project management 


\section{Civil Engineering Research Journal}

practitioners, contractors, and clients) who have been involved in an uncompleted (abandoned) public sector Community Day Senior High School building construction projects. Results were analysed using thematic and content analysis techniques.

The findings indicate that the impact of the Community Day School building construction project abandonment has three main effects on the beneficiaries. These effects are social, economic and politically related. However, the three effects are intertwined, cyclical and vicious. Thus, there several immediate social effects on the beneficiaries but these social effects have long-term economic and political implications for the citizens in the form of citizens' economic development and their attitude towards governments and their voting behaviour in general elections. Unlike prior studies that have often assessed effects of construction projects abandonment on the projects being assessed [7], with little attention paid to key stakeholders associated with the project this study assessed effects of abandonment of school building construction projects on the beneficiaries-an area that has been neglected by researchers. Policymakers and practitioners will be able to understand the effects of school building construction projects abandonment. This will help them to devise strategies that will help reduce or avoid such abandonment and its subsequent effects on the stakeholders-beneficiaries. Further, researchers would be able to use findings as a foundation for further studies into the public sector school building projects abandonment phenomenon in general and effects.

\section{Limitations and future research}

The main caveat of this study is that we used quota in the data selection and as such it may be represent the views of the entire population. However, since we do not intend to make generalizations as this is an exploratory study, further studies could increase the sample size to improve generalizations. Given that individuals were contacted on the basis that they have been involved in abandoned public sector building construction projects, we have no reason to doubt their views.

\section{References}

1. Goodman LJ, Love RS (1980) Project Planning and Management: An Integrated Approach. Pergamon Press, New York, USA.

2. Heeks R (2002) Failure, Success and Improvisation of Information System Projects in Developing Countries. Development Informatics Working Paper Series, Institute for Development Policy and Management Manchester, UK.

3. Ayodele EO, Alabi OM (2011) Abandonment of Construction Projects in Nigeria: Causes and Effects. Journal of Emerging Trends in Economics and Management Sciences 2(2): 142-145.

4. Olalusi O, Otunola A (2012) Abandonment of Projects in Nigeria - A review of causes and solution. Paper presented at the international conference on chemical, civil and environment engineering, (ICCEE 2012) Dubai.

5. Mac-Barango D (2017) Construction Project Abandonment: An Appraisal of Causes, Effects and Remedies. World Journal of Innovation and Modern Technology 1(1): 2504-4766.
6. Efenudu FO (2010) Causes and Effect of Abandonment of Project on Property Value: A Case of Port Harcourt. Unpublished First-Degree Dissertation, Department of Estate Management, Faculty of Environmental Sciences, Rivers State University of Science and Technology Nigeria.

7. Pourrostam T, Ismail A (2011) Significant Factors Causing and effects of Delay in Iranian Construction Projects. Australian Journal of Basic and Applied Sciences 5(7): 45-450.

8. Amoatey CT, Ameyaw YA, Adaku E, Famiyeh S (2015) Analyzing delay causes and effects in Ghanaian state housing construction projects. International Journal of Managing Projects in Business 8(1): 198-214.

9. Republic of Ghana Budget (2012) Theme - Infrastructural Development for Accelerated Growth and Job Creation. Highlights of the Budget; Ministry of Finance and Economic Planning. Accra Ghana.

10. Republic of Ghana Budget (2018) The Budget statement and economic policy of the Government of Ghana for the Government of Ghana for the Financial Year.

11. Mingle J (2012) Commentary on STX housing project.

12. Mensah ET (2012) Ghana has gone beyond era of abandoning projects by previous governments.

13. Kwofie TE, Afram S, Botchway E (2016) A critical success model for PPP public housing delivery in Ghana. Built Environment Project and Asset Management 6(1): 58-73.

14. Mensah A (2018) We will complete works on the Chirano Community Day SHS - President Assures residents.

15. Freeman RE (1984) Strategic Management: A Stakeholder Approach. Boston: Pitman. Latest edition Strategic Management: A Stakeholder Approach.

16. Heath J, Norman W (2004) Stakeholder Theory, Corporate Governance and Public Management: What can the history of state-run enterprises teach us in the post-Enron era? Journal of Business Ethics 53(3): 247265.

17. Pan GSC (2005) Information systems project abandonment: a stakeholder analysis. International Journal of Project Management 25(2): 173-184.

18. Pan G, Pan SL (2006) Examining the coalition dynamics affecting IS project abandonment decision-making. Decision Support Systems 42(2): 639-655.

19. Olander S (2007) Stakeholder impact analysis in construction project management. Construction Management and Economics 25(3): 277287.

20. Sæbø Ø, Flak LS, Sein MK (2011) Understanding the dynamics in e-Participation initiatives: Looking through the genre and stakeholder lenses. Government Information Quarterly 28(3): 416-425.

21. Axelsson K, Melin U, Lindgren I (2013) Public e-services for agency efficiency and citizen benefit - Findings from a stakeholder centered analysis. Government Information Quarterly 30(1): 10-22.

22. Elias AA, Cavana RY, Jackson LS (2002) Stakeholder analysis for R \& D project management. R\&D Management 32(4): 301-310.

23. Flak LS, Nordheim S (2006) Stakeholders, contradictions and salience: An empirical study of a Norwegian G2G effort. Proceedings of the $39^{\text {th }}$ annual Hawaii international conference on system sciences (HICSS). Hawaii, USA.

24. Alexander I, Stevens R (2002) Writing better requirements. Addison Wesley, Reading.

25. Alexander I, Robertson S (2004) Understanding project sociology by modeling stakeholders. IEEE Software IEEE Computer Society 21(1): 23-27. 


\section{Civil Engineering Research Journal}

26. Mitchell RK, Agle RB, Wood JD (1997) Toward a Theory of Stakeholder Identification and Salience: Defining the Principle of Who and What Really Counts. The Academy of Management Review 22(4): 853-886.

27. Damoah IS, Kumi DK, Yusra M (2018) The effects of government construction projects abandonment: stakeholders' perspective. International Journal of Construction Management.

28. Manavazhia MR, Adhikarib DK (2002) Material and equipment procurement delays in highway projects in Nepal. International Journal of Project Management 20(8): 627-632.

29. Ngacho C, Das D (2014) A performance evaluation framework of development projects: An empirical study of Constituency Development Fund (CDF) construction projects in Kenya. International Journal of Project Management 32(3): 492-507.

30. Foddy W (1994) Constructing Questions for Interviews and Questionnaires. Cambridge: Cambridge University Press.

31. Miles M, Huberman M (1994) The Handbook of Social Work Research Method. Sage Publication, London.

32. Braun V, Clarke V (2012) Thematic analysis. In: Cooper H, Camic PM Long DL, Panter AT, Rindskopf D, et al. (Edt.), APA handbook of research methods in psychology, Research designs: Quantitative, qualitative, neuropsychological, and biological. US: American Psychological Association. Washington, DC, USA, p. 57-71.

33. Amponsah R (2010) Improving Project Management Practice in Ghana with Focus on Agriculture, Banking and Construction Sectors of the Ghanaian Economy. A thesis submitted in fulfillment of the requirements for the Degree of Doctor of Project Management, School of Property, Construction and Project Management RMIT University.

34. Damoah IS, Akwei C (2017) Government project failure in Ghana: a multidimensional approach. International Journal of Managing Projects in Business 10(1): 32-59.

35. Damoah IS, Akwei C, Mouzughi Y, (2015) Causes of government project failure in developing countries - Focus on Ghana. In: The Value of Pluralism in Advancing Management Research, Education and Practice. $29^{\text {th }}$ Annual BAM Conference 8-10 September. University of Portsmouth, UK.

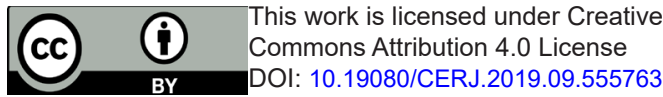

36. Eichengreen B (1994) Restructuring and Adjustment: perspectives from Post-World II Europe. Institutional prerequisites for economic growth: Europe after World War II. European Economic Review 38 883-890.

37. Eichengreen B (1996) Institutions and Economic Growth: Europe Since World War II, in N. F. R. Crafts and Gianni Toniolo (eds), Economic Growth in Europe Since 1945, Cambridge: Cambridge University Press, USA, p. 38-72.

38. Eichengreen B, Vazquez P (1999) Institutions and Economic Growth in Postwar Europe: Evidence and Conjectures. Productivity, Technology and Economic Growth p. 91-128.

39. Ahsan K, Gunawan I (2010) Analysis of cost and schedule performance of international developmental projects. International Journal of Project Management 28(1): 68-78.

40. Yang RJ (2014) An investigation of stakeholder analysis in urban development projects: Empirical or rationalistic perspectives. International Journal of Project Management 32(5): 838-849.

41. Pinto JF (2013) Lies, damned lies, and project plans: Recurring human errors that can ruin the project planning process. Business Horizons 56(5): 643-653.

42. Ainuddin RA, Beamish PW, Hulland JS, Rouse MJ (2007) Resource attributes and firm performance in international joint ventures. Journal of World Business 42: 47-60.

43. Damoah IS, (2015) An investigation into the causes and effects of project failure in government projects in developing countries: Ghana as a case study. A thesis submitted in fulfillment of the requirements for the Degree of Doctor of Project Management. Liverpool John Moores University.

44. Republic of Ghana Budget (2015) Highlights of the Budget; Ministry of Finance and Economic Policy. Accra, Ghana.

\section{Your next submission with Juniper Publishers will reach you the below assets}

- Quality Editorial service

- Swift Peer Review

- Reprints availability

- E-prints Service

- Manuscript Podcast for convenient understanding

- Global attainment for your research

- Manuscript accessibility in different formats

( Pdf, E-pub, Full Text, Audio)

- Unceasing customer service

Track the below URL for one-step submission

https://juniperpublishers.com/online-submission.php 